\title{
Detection of tick-borne pathogens in wild birds and their ticks in Western Siberia and high level of their mismatch
}

\author{
Igor G. Korobitsyn ${ }^{1}$, Nina S. Moskvitina ${ }^{1}$, Oleg Yu. Tyutenkov ${ }^{1}$, Sergey I. Gashkov ${ }^{1}$, Yulia V. Kononova ${ }^{2}$, \\ Sergey S. Moskvitin ${ }^{1}$, Vladimir N. Romanenko ${ }^{1}$, Tamara P. Mikryukova ${ }^{2}$, Elena V. Protopopova ${ }^{2}$, Mikhail Yu. \\ Kartashov $^{2}$, Eugene V. Chausov ${ }^{2}$, Svetlana N. Konovalova ${ }^{2}$, Natalia L. Tupota ${ }^{2}$, Alexandra O. Sementsova ${ }^{2}$, \\ Vladimir A. Ternovoi ${ }^{2}$ and Valery B. Loktev ${ }^{2}$
}

\author{
${ }^{1}$ Tomsk State University, Tomsk, Russia; \\ ${ }^{2}$ State Research Centre of Virology and Biotechnology 'Vector', World-Class Genomic Research Center for Biological Safety and \\ Technological Independence, Koltsovo, Novosibirsk Region, Russia
}

\begin{abstract}
The Tomsk region located in the south of Western Siberia is one of the most high-risk areas for tick-borne diseases due to elevated incidence of tick-borne encephalitis and Lyme disease in humans. Wild birds may be considered as one of the reservoirs for tick-borne pathogens and hosts for infected ticks. A high mobility of wild birds leads to unpredictable possibilities for the dissemination of tick-borne pathogens into new geographical regions. The primary goal of this study was to evaluate the prevalence of tick-borne pathogens in wild birds and ticks that feed on them as well as to determine the role of different species of birds in maintaining the tickborne infectious foci. We analysed the samples of 443 wild birds ( 60 species) and 378 ticks belonging to the genus Ixodes Latraille, 1795 collected from the wild birds, for detecting occurrence of eight tick-borne pathogens, the namely tick-borne encephalitis virus (TBEV), West Nile virus (WNV), and species of Borrelia, Rickettsia, Ehrlichia, Anaplasma, Bartonella and Babesia Starcovici, 1893, using RT-PCR/or PCR and enzyme immunoassay. One or more tick-borne infection markers were detected in 43 species of birds. All markers were detected in samples collected from fieldfare Turdus pilaris Linnaeus, Blyth's reed warbler Acrocephalus dumetorum Blyth, common redstart Phoenicurus phoenicurus (Linnaeus), and common chaffinch Fringilla coelebs Linnaeus. Although all pathogens have been identified in birds and ticks, we found that in the majority of cases $(75.5 \%)$, there were mismatches of pathogens in birds and ticks collected from them. Wild birds and their ticks may play an extremely important role in the dissemination of tick-borne pathogens into different geographical regions.
\end{abstract}

Keywords: birds, Ixodes, WNV, TBEV, Borrelia spp., Rickettsia spp., Anaplasma spp., Bartonella spp., Ehrlichia spp., Babesia spp.

The prevalence of vector-borne diseases in the world has remained a very relevant concern. Numerous studies have demonstrated an important role of wild birds in spreading parasites and pathogens. Wild birds also serve as reservoirs for viruses, bacteria and protists that are pathogenic for humans (Hubálek 2004, Tsiodras et al. 2008, Hasle 2013).

The Tomsk region, where we conducted this study, is one of the most high-risk areas for tick-borne diseases due to elevated incidence of tick-borne encephalitis and Lyme disease in humans (State Report Tomsk 2017). The major vector for these diseases in the western part of Russia is Ixodes persulcatus Schulze, 1930. Since the beginning of the 21 st century, another tick with similar ecology, Ixodes pavlovskyi Pomerantsev, 1946, has been found in the same habitats (Romanenko and Chekalkina 2004) and currently predominates over I. persulcatus in urban areas. Although both ticks can bite humans, I. pavlovskyi is also known as an ornithophilic tick (Ushakova et al. 1969, Moskvitina et al. 2014). Its disjunct habitat range includes the mountain territories in the Russian Far East, Altai, and Gornaya Shoriya, and its appearance in the Tomsk region is probably caused by wild birds. The prevalence of tick-borne encephalitis virus (TBEV) and Borrelia spp. in questing ticks in the Tomsk region has been estimated to be up to $9.3 \%$ and $28.5 \%$, respectively (Moskvitina et al. 2014, Pankina et al. 2015).

There are 333 species of birds in the Tomsk region and more than 250 of them have annual migration (Ryabitsev et al. 2001). The geographical location of this region in the Eurasian continent provides a wide range of directions for the migration of wild birds to the wintering grounds. According to the data of ringing (Moskvitin and Dubovik 1969, 1977, Moskvitin and Strelkov 1977, Moskvitin 1992, Ryabitsev 2001), Siberian birds spend the winter in Africa, Europe, West Asia, India, and Southeast Asia (Fig. 1). This creates preconditions for the dispersion of pathogens from 


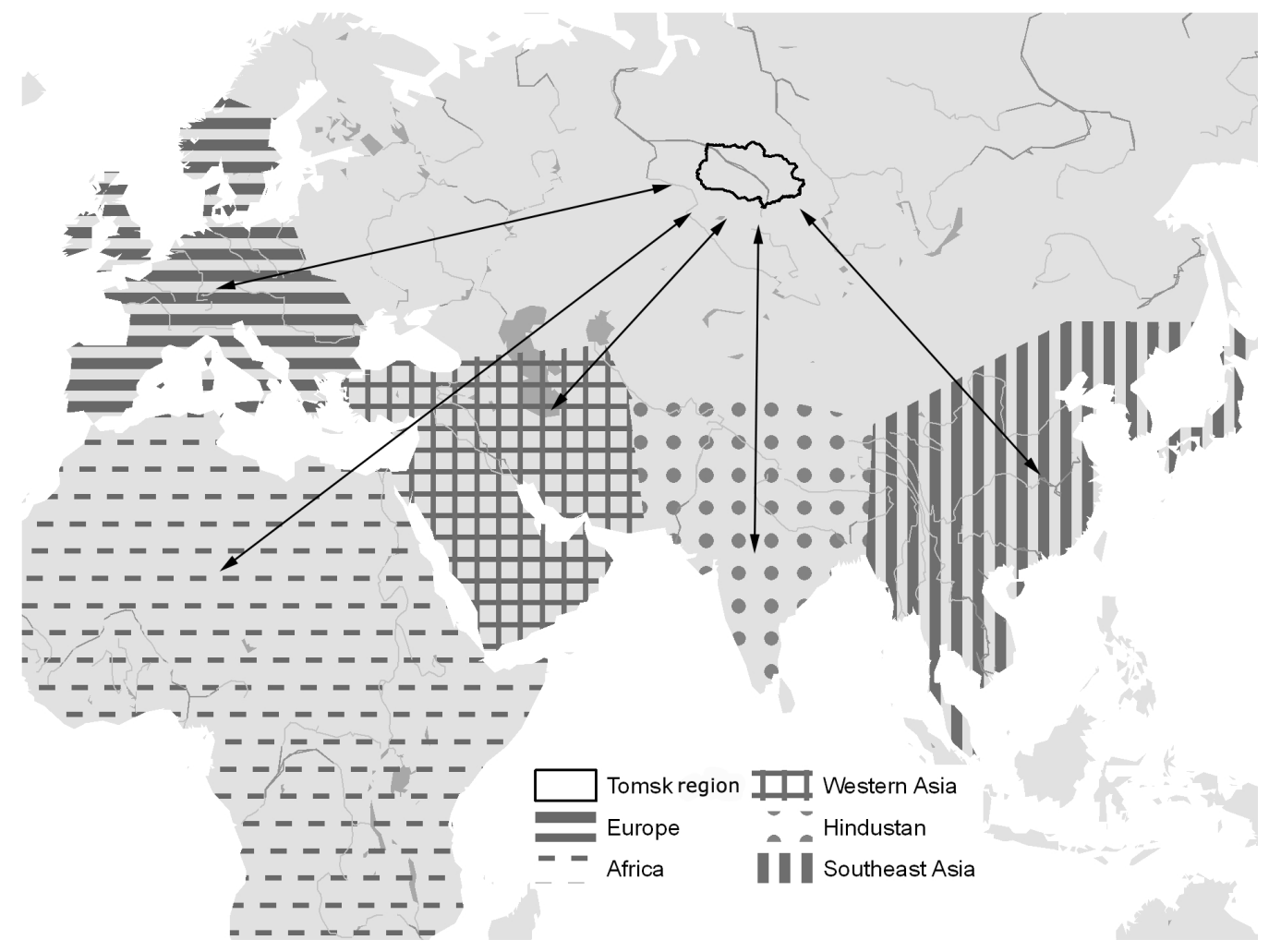

Fig. 1. Scheme of the wintering grounds of wild birds from Western Siberia.

different areas with various epidemiological settings. Numerous pathogens have been found in ticks and vertebrate hosts in the Tomsk region (Chausov et al. 2010). In addition to TBEV and Borrelia spp., some other pathogens such as species of Rickettsia, Anaplasma, Babesia, Ehrlichia, and Bartonella were also found. Surprisingly, West Nile virus (WNV) was found in ticks from the genus Ixodes Latraille, 1795, which attack both humans and vertebrates. We assumed that the circulation of WNV in the tick vertebral system is theoretically possible (Moskvitina et al. 2008, 2014), which has been previously demonstrated experimentally (Azarova and Mishaeva 2002). Although several studies have focused on the detection of various pathogens in birds and ticks collected from them (Hildebrandt et al. 2010, Špitalská et al. 2011, Dubska et al. 2012, Kang et al. 2013, Movila et al. 2013, Toma et al. 2014, Diakou et al. 2016), there is no clear information on the relationship between pathogens, vectors, and hosts. Therefore, this study was conducted to identify the pathogens that were detected in different species of birds and ticks parasitising on them and to evaluate their interdependence.

\section{MATERIALS AND METHODS}

\section{Bird capture and tick collection}

Fieldwork was conducted from April to August during 20062011. The study material was collected in Tomsk $(56.4826 \mathrm{~N}$, $84.9950 \mathrm{E})$ and their nearest suburbs within $15 \mathrm{~km}$ zone. Altogether, 736 wild birds were examined for the presence of feeding ticks, of which 293 birds were captured using mist nets and subsequently released and 443 were shot during the hunt and sub- sequently analysed for the presence of pathogens. A total of 804 larvae, nymphs and adults from the genus Ixodes were collected from the birds. Feeding ticks were analysed for the presence of pathogens. We have previously reported the prevalence and intensity of tick infection in birds (Moskvitina et al. 2014). Ticks from each bird were collected separately in Eppendorf tubes and after their species identification using a taxonomic guide (Filippova 1977), they were stored alive at $4^{\circ} \mathrm{C}$ or frozen at $-20^{\circ} \mathrm{C}$ until the detection of pathogens. The identification of bird species was performed according to a field guide (Ryabitsev 2001). All procedures involving wild birds were conducted according to permits 70 No. 024401 and 70 No. 024399 from the local government and regulations for working with wild animals.

\section{Detection of selected pathogens}

A total of 443 specimens of 60 species of birds (spleen, liver, and brain) and 378 ticks (all stages) were examined for the presence of eight pathogens (TBEV, WNV, spp. of Borrelia, Rickettsia, Ehrlichia, Anaplasma, Bartonella, and Babesia).

\section{Enzyme immunoassay}

TBEV antigens were detected via enzyme immunoassay analysis as described previously (Ternovoi et al. 2007). Briefly, the viral antigen was captured on the surface of 96-well polystyrene plates from $100 \mu \mathrm{l}$ of the homogenates of ticks and internal organs (spleen, liver and brain from individual bird) using monoclonal antibodies $10 \mathrm{H} 10$ against protein E of TBEV that was preliminarily immobilised on the plates. Immune complexes were detected using EB1 monoclonal antibody against protein E of TBEV labeled with biotin, which was identified by avidin-peroxidase. WNV antigens were detected using a previously described 

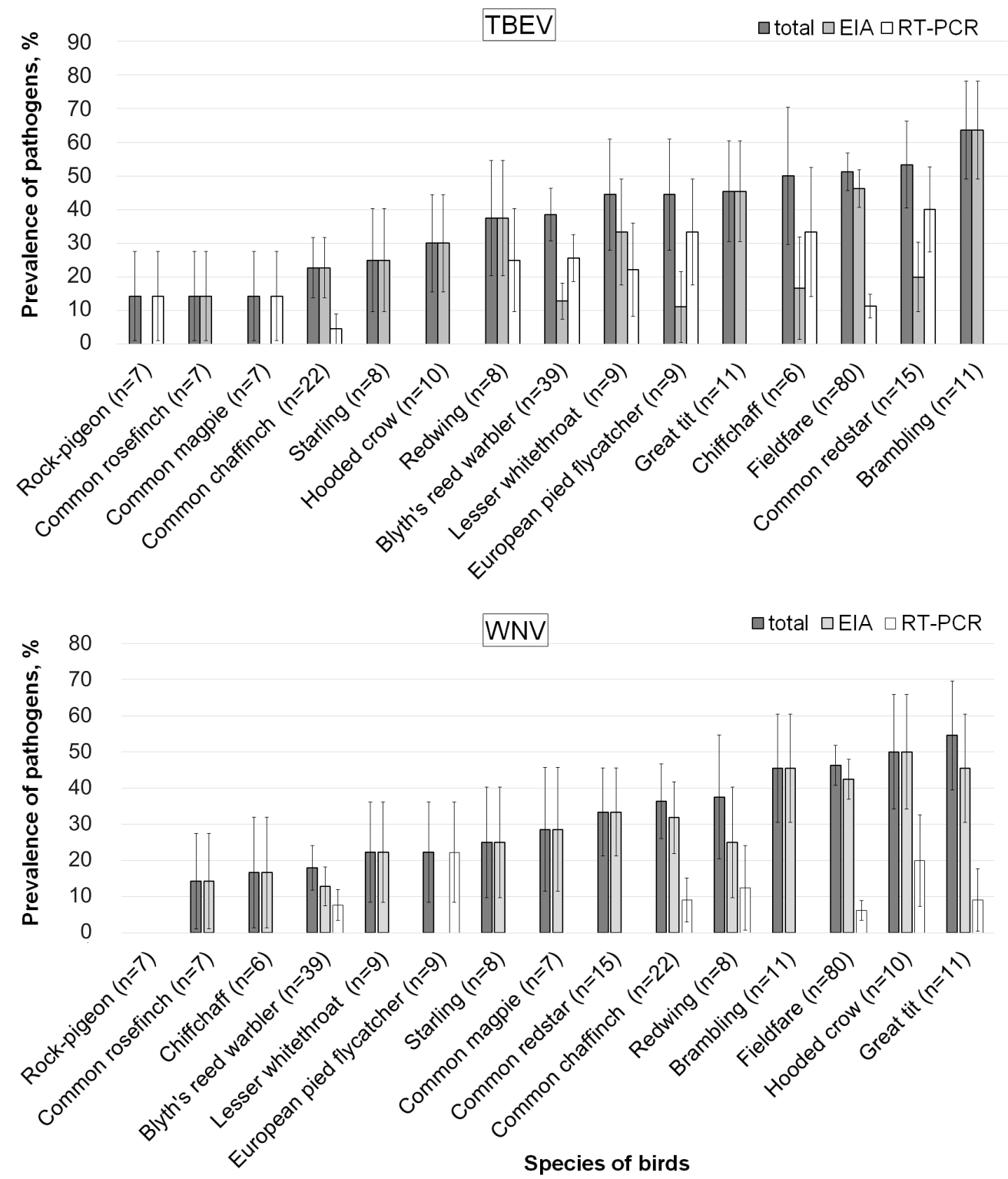

Fig. 2. Prevalence of TBEV and WNV markers (total, viral antigen, and RNA) in wild birds.

technique (Ternovoi et al. 2004). WNV antigens were captured on the surface of 96 -well plates from $10 \%$ homogenates of samples of animals (ticks and birds) by the enzyme immunoassay analysis using a mixture of three purified murine monoclonal antibodies, $3 \mathrm{~A} 6,6 \mathrm{H} 4$, and 2B9, against WNV. The immune complex was detected using murine polyclonal antiviral IgG labeled with biotin and streptavidin peroxidase. Samples were considered as positive if the signal exceeded the negative control by two or more times.

\section{PCR analysis}

RNA extraction, reverse transcription, and detection of TBEV and WNV cDNA using RT-PCR, as well as the detection of other bacterial and protozoan pathogens using PCR, were performed as described earlier (Chausov et al. 2010). Briefly, a combined RNA/DNA mixture was extracted from $100 \mu$ l of the homogenate of ticks and organs of birds using a RIBOSorb (AmpliSens, Moscow, Russia) set and a DNA/RNA Extraction Kit (NPF Litekh, Moscow, Russia), according to the manufacturers' instructions. Synthesis of cDNA was performed using a REVERTA-L kit (Am-
pliSens, Moscow, Russia) according the manufacturer's protocol. We calculated and synthesised the oligonucleotide primers for detecting the RNA and DNA of TBEV, WNV, and species of Borrelia, Rickettsia, Ehrlichia, Babesia, and Bartonella based on the comparison of the nucleotide sequences of their different strains deposited in GenBank. Table 1 shows the primer pairs for the amplification of the sequences of viral, bacterial, and protozoan agent markers.

\section{Comparison of pathogens in birds and ticks}

In 45 cases, we conducted pairwise comparisons of the pathogens in birds and ticks that feed on them. All analysed ticks were engorged with blood. Among all the cases of pairwise comparisons of pathogens between birds and ticks feeding on them, we made the following statement: If the infected birds were carriers of uninfected ticks (irrespective of how many uninfected ticks were on the bird and what development stages and species they were), these cases were considered as one event of comparison. The same situation was considered if ticks on one bird were in- 
Table 1. Oligonucleotide primers used in the study

\begin{tabular}{|c|c|c|c|}
\hline Name & Pathogen, target gene & Sequence & $\begin{array}{l}\text { Length of } \\
\text { PCR, bp }\end{array}$ \\
\hline $\begin{array}{l}\text { TBElf } \\
\text { TBE2r }\end{array}$ & TBEV, 5'-end & $\begin{array}{l}\text { AGATTTTCTTGCACGTGCRTGCGTTTG } \\
\text { CCCAKCATGCGCATCAAC }\end{array}$ & 240 \\
\hline $\begin{array}{l}\text { WNlf } \\
\text { WN2r }\end{array}$ & WNV, protein E & $\begin{array}{l}\text { CCTTGGWATGAGCAACAGAGACTTC } \\
\text { GTGTCAATRCTTCCTTTGCCAAATA }\end{array}$ & 336 \\
\hline $\begin{array}{l}\text { Borrlf } \\
\text { Borr2r }\end{array}$ & Borrelia spp., flagellin gene & $\begin{array}{l}\text { TTAGCAGTTCAATCAGGTTAACG } \\
\text { CAACCTCATCTGTCATTGTAGC }\end{array}$ & 636 \\
\hline $\begin{array}{l}\text { Ricklf } \\
\text { Rick2r }\end{array}$ & Rickettsia spp., citrate synthase gene & $\begin{array}{l}\text { TCTCATCCTATGGCTATTATGCTTGC } \\
\text { ATAAATATYTTATTAAGAGCATTTTTTTT }\end{array}$ & 286 \\
\hline $\begin{array}{l}\text { Bab1f } \\
\text { Bab2r }\end{array}$ & Babesia spp., 18S RNA & $\begin{array}{l}\text { GTAGGACTTTGGTTCTATTTTG } \\
\text { GTCAATCCTACCGTTTGTCTGG }\end{array}$ & 442 \\
\hline $\begin{array}{l}\text { Bart1f } \\
\text { Bart2r }\end{array}$ & Bartonella spp., hemin binding protein gene & $\begin{array}{l}\text { ACTTCTGTTATCGCTTTRRTTTC } \\
\text { TCACCACCAGCAACATAAGGCATAAT }\end{array}$ & 525 \\
\hline $\begin{array}{l}\text { Ehrl1f } \\
\text { Ehrllr }\end{array}$ & Ehrlichia spp., disulphide oxidoreductase gene & $\begin{array}{l}\text { TTGCAAAATGATGTCTGAAGATATGAAACA } \\
\text { GCTGCTCCACCAATAAATGTATCYCCTA }\end{array}$ & 377 \\
\hline $\begin{array}{l}\text { HS1-f } \\
\text { HS6-r }\end{array}$ & Anaplasma ssp., groESL operon (Sumner et al. 1997) & $\begin{array}{l}\text { CGYCAGTGGGCTGGTAATGAA } \\
\text { CCWCCWGGTACWACACCTTC }\end{array}$ & $1320-1360$ \\
\hline
\end{tabular}

Note: The usability of the primers for detection of tick-borne infection markers has been confirmed by sequencing as described by us for: TBEV (Ponomareva et al. 2021); West Nile virus, genotype I (MN149538 isolated from Acrocephalus dumetorum Blyth); Borrelia spp. (EU919255, MN193533 for B. garinii and MN986989 for B. miyamotoi); Rickettsia spp. (MK304547 for R. raoultii and KP866150 for R. helvetica); Ehrlichia spp. (EU919250 for E.muris and Kartashov et al. 2020); Anaplasma spp. (Kartashov et al. 2019); Bartonella spp. and Babesia spp. (MH424325 for B. caballi and Rar et al. 2005).

fected with a pathogen common for all ticks that fed on this bird. If the infected or uninfected bird was a carrier of several ticks each of which was infected with a different set of pathogens, every case of comparison of the pathogens in this bird and each tick was considered as an independent event. By the term "event" we mean one pairwise comparison of pathogens in a bird and in a tick (or ticks) feeding on it. We excluded from the analysis those cases when both the bird and the tick were free of pathogens.

\section{Statistical analysis}

Statistica 6.0 and Microsoft Office Excel 2007 were used to perform statistical analysis. The F-test was used to confirm the differences in the rates of infected animals. The Spearman method was used to evaluate the correlations of some parameters.

\section{RESULTS}

\section{Pathogens detected in wild birds}

A total of 60 species of wild birds were examined for the presence of the above-mentioned tick-borne pathogens. We found that 43 species $(71.7 \%)$ were the carriers of some pathogens (Table 2). Some species among individually analysed birds had one to eight infection agents, which were detected in their samples. The number of pathogens in some species of birds did not always depend on the number of analysed samples of that species of birds. Sometimes, the number of pathogen markers was higher in species with a small sample (the common willow $(n=2)$ had four pathogens and the Eurasian nuthatch $(\mathrm{n}=3)$ had five pathogens; scientific names of birds are in Table 2) than in species with a larger sample (the great tit $(\mathrm{n}=11)$ had only three pathogens and the garden warbler $(n=5)$ had only one pathogen).

We assumed that some species of birds were more or less susceptible to pathogens and, consequently, played a different role as reservoirs. To illustrate this assumption, we estimated the percentage of birds of different species infected by TBEV and WNV (Fig. 2). We confirmed that the species had a different percentage of prevalence of viral infections. For some species, but not all, the percentage of birds infected with viruses was associated with the frequency of their contact with ticks. For instance, the fieldfare, whose mean abundance of parasites was 5.7 ticks per bird, had one of the highest percentages of viral infection markers of approximately $50 \%$ (Fig. 2). In contrast, birds rarely attacked by ticks, such as the rock pigeon, the common rosefinch, and the magpie, whose mean abundance were $0,0.3$, and 0.5 ticks per bird, respectively, had a low prevalence of viruses. However, there were also such species (the hooded crow, the great tit and the brambling) that were not in close contact with ticks but showed a high prevalence of infections, probably due to their susceptibility.

Regarding the methods of detecting viral infections, the viral antigen, compared with the viral RNA, was detected more often for TBEV markers by 1.6 times and for WNV markers by 4.6 times. In some species, RNA could be detected more often than the antigen. Simultaneously, both methods confirmed the presence of TBEV markers in birds in $7.3 \%$ of cases and WNV markers in $6.3 \%$ of cases.

The number of pathogens was almost similar in the groups of sedentary and migratory birds. There were also no significant differences in the percentage of birds infected with certain pathogens in both groups, except that of species Borrelia and Bartonella (Table 3). The mass departure of Siberian birds from nest sites to the wintering areas after tick parasitisation can result in the distribution and exchange of pathogens between the territories.

\section{Number of pathogens in birds against number of ticks}

We attempted to verify whether the number of pathogens in birds that play the major role in sustaining the tick population (the tree pipit, the fieldfare and the redwing) was in fact higher than that in birds that have less contact with ticks (the European pied flycatcher and the lesser whiteth- 
Table 2. Species of wild birds with infections markers in Western Siberia and places of their wintering ground

\begin{tabular}{|c|c|c|c|c|c|c|c|c|c|}
\hline \multirow[b]{2}{*}{ Species of birds ${ }^{a}$} & \multicolumn{8}{|c|}{ Number of infected/examined birds } & \multirow[b]{2}{*}{$\begin{array}{l}\text { Migratory }(\mathrm{M}) \text { / seden- } \\
\text { tary }(\mathrm{S}) \text { status of birds } \\
\text { and geographic location } \\
\text { of wintering grounds }\end{array}$} \\
\hline & $\begin{array}{c}\text { Total infected } \\
\text { (antigen/RNA) } \\
\text { examined }\end{array}$ & $\begin{array}{c}\text { Total infected } \\
/(\text { antigen/RNA }) / \\
\text { examined }\end{array}$ & 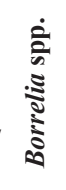 & 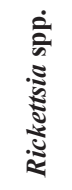 & 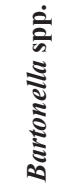 & 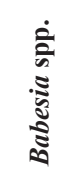 & 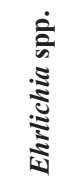 & 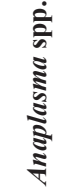 & \\
\hline Fieldfare Turdus pilaris Linnaeus & $41(37 / 9) / 80$ & $37(34 / 5) / 80$ & $8 / 80$ & $7 / 80$ & $5 / 22$ & $3 / 22$ & $2 / 22$ & $2 / 22$ & M, Europe \\
\hline $\begin{array}{l}\text { Blyth's reed warbler Acrocephalus dumetorum } \\
\text { Blyth }\end{array}$ & $15(5 / 0) / 39$ & $7(5 / 3) / 39$ & $4 / 39$ & $8 / 39$ & $1 / 13$ & $1 / 13$ & $1 / 13$ & $3 / 13$ & M, India \\
\hline $\begin{array}{l}\text { Common redstart Phoenicurus phoenicurus } \\
\text { (Linnaeus) }\end{array}$ & $8(3 / 6) / 15$ & $5(5 / 0) / 15$ & $2 / 15$ & $3 / 15$ & $1 / 4$ & $2 / 4$ & $1 / 4$ & $1 / 4$ & M, Africa \\
\hline Common chaffinch Fringilla coelebs Linnaeus & $5(5 / 1) / 22$ & $8(7 / 2) / 22$ & $2 / 22$ & $1 / 22$ & $2 / 12$ & $2 / 12$ & $2 / 12$ & $1 / 12$ & M, Kaspian and Near East \\
\hline $\begin{array}{l}\text { European pied flycatcher } \\
\text { Ficedula hypoleuca (Pallas) }\end{array}$ & $4(1 / 3) / 9$ & $2(0 / 2) / 9$ & $1 / 9$ & $1 / 9$ & $2 / 4$ & $1 / 4$ & $0 / 4$ & $0 / 4$ & M, Africa \\
\hline Brambling Fringilla montifringilla Linnaeus & $7(7 / 0) / 11$ & $5(5 / 0) / 11$ & $0 / 11$ & $2 / 11$ & $0 / 3$ & $1 / 3$ & $0 / 3$ & $1 / 3$ & M, Europe and India \\
\hline Eurasian nuthatch Sitta europaea Linnaeus & $1(1 / 0) / 3$ & $2(2 / 0) / 3$ & $0 / 3$ & $1 / 3$ & $0 / 1$ & $1 / 1$ & $0 / 1$ & $1 / 1$ & $\mathrm{~S}$ \\
\hline Lesser whitethroat Sylvia curruca (Linnaeus) & $4(3 / 2) / 9$ & $2(2 / 0) / 9$ & $1 / 9$ & $0 / 9$ & $1 / 4$ & $0 / 4$ & $0 / 4$ & $1 / 4$ & M, Africa and India \\
\hline Sand martin Riparia riparia ${ }^{\text {b }}$ (Linnaeus) & $10(3 / 7) / 48$ & $4(4 / 0) / 48$ & $9 / 21$ & $3 / 21$ & $0 / 21$ & $0 / 21$ & $0 / 21$ & $2 / 21$ & M, Africa and India \\
\hline Hooded crow Corvus cornix Linnaeus & $3(3 / 0) / 10$ & $5(5 / 2) / 10$ & $1 / 10$ & $1 / 10$ & n.a. ${ }^{\mathrm{c}}$ & n.a. & n.a. & n.a. & $\mathrm{S}$ \\
\hline Willow warbler Phylloscopus trochilus (Linnaeus) & $2(2 / 1) / 2$ & $2(2 / 0) / 2$ & $1 / 2$ & $1 / 2$ & $0 / 1$ & $0 / 1$ & $0 / 1$ & $0 / 1$ & M, Arfica \\
\hline Common rosefinch Carpodacus erythrinus (Pallas) & $1(1 / 0) / 7$ & $1(1 / 0) / 7$ & $1 / 7$ & $1 / 7$ & $0 / 2$ & $0 / 2$ & $0 / 2$ & $0 / 2$ & M, India and South-East Asia \\
\hline Rock-pigeon Columba livia Gmelin & $1(0 / 1) / 7$ & $0 / 7$ & $0 / 7$ & $4 / 7$ & $0 / 7$ & $1 / 7$ & $0 / 7$ & $3 / 7$ & $\mathrm{~S}$ \\
\hline Redwing Turdus illiacus Linnaeus & $3(3 / 2) / 8$ & $3(2 / 1) / 8$ & $0 / 8$ & $1 / 8$ & $2 / 4$ & $0 / 4$ & $0 / 4$ & $0 / 4$ & M, Europe \\
\hline Common woodcock Scolopax rusticola Linnaeus & $0 / 5$ & $1(1 / 0) / 5$ & $0 / 5$ & $1 / 5$ & $1 / 4$ & $1 / 4$ & $0 / 4$ & $0 / 4$ & M, Europe \\
\hline Chiffchaff Phylloscopus collybita (Vieillot) & $3(1 / 2) / 6$ & $1(1 / 0) / 6$ & $0 / 6$ & $1 / 6$ & $0 / 4$ & $0 / 4$ & $0 / 4$ & $0 / 4$ & M, Europe and Africa \\
\hline Tree pipit Anthus trivialis (Linnaeus) & $3(0 / 3) / 3$ & $0 / 3$ & $2 / 3$ & $1 / 3$ & $0 / 1$ & $0 / 1$ & $0 / 1$ & $0 / 1$ & M, Africa and India \\
\hline European greenfinch Chloris chloris (Linnaeus) & $1(1 / 0) / 2$ & $2(1 / 1) / 2$ & $0 / 2$ & $1 / 2$ & n.a. & n.a. & n.a. & n.a. & M, Europe and Kaspian \\
\hline Great tit Parus major Linnaeus & $5(5 / 0) / 11$ & $6(5 / 1) / 11$ & $0 / 11$ & $2 / 11$ & $0 / 3$ & $0 / 3$ & $0 / 3$ & $0 / 3$ & $\mathrm{~S}$ \\
\hline Common bullfinch Phyrrhula phyrhula (Linnaeus) & $2(2 / 0) / 4$ & $1(1 / 0) / 4$ & $0 / 4$ & $1 / 4$ & $0 / 2$ & $0 / 2$ & $0 / 2$ & $0 / 2$ & $\mathrm{~S}$ \\
\hline Starling Sturnus vulgaris Linnaeus & $2(2 / 0) / 8$ & $2(2 / 0) / 8$ & $0 / 8$ & $1 / 8$ & n.a. & n.a. & n.a. & n.a. & M, Africa, Europe and India \\
\hline Eurasian tree sparrow Passer montanus (Linnaeus) & $3(3 / 0) / 3$ & $3(3 / 0) / 3$ & $0 / 3$ & $0 / 3$ & n.a. & n.a. & n.a. & n.a. & $\mathrm{S}$ \\
\hline Yellow hammer Emberiza citronella Linnaeus & $2(2 / 0) / 4$ & $2(2 / 0) / 4$ & $0 / 4$ & $0 / 4$ & n.a. & n.a. & n.a. & n.a. & M, Middle Asia, partially sedentary \\
\hline Jackdaw Corvus monedula Linnaeus & $1(1 / 0) / 4$ & $3(3 / 1) / 4$ & $0 / 4$ & $0 / 4$ & n.a. & n.a. & n.a. & n.a. & M, Middle Asia \\
\hline Lapwing Vanellus vanellus (Linnaeus) & $2(0 / 2) / 8$ & $2(0 / 2) / 8$ & $0 / 8$ & $0 / 8$ & n.a. & n.a. & n.a. & n.a. & M, Europe and Kaspian \\
\hline Mallard Anas platyrhynchos Linnaeus & $4(0 / 4) / 35$ & $0 / 35$ & $1 / 35$ & $0 / 35$ & n.a. & n.a. & n.a. & n.a. & M, Kaspian and India \\
\hline Pallas' warbler Phylloscopus proregulus (Pallas) & $1(0 / 1) / 1$ & $0 / 1$ & $0 / 1$ & $0 / 1$ & $1 / 1$ & $0 / 1$ & $0 / 1$ & $0 / 1$ & M, South-East Asia \\
\hline Siberian rubythroat Luscinia calliope (Pallas) & $2(1 / 2) / 3$ & $0 / 3$ & $1 / 3$ & $0 / 3$ & $0 / 1$ & $0 / 1$ & $0 / 1$ & $0 / 1$ & M, South-East Asia \\
\hline Goldfinch Carduelis carduelis (Linnaeus) & $2(0 / 2) / 4$ & $0 / 4$ & $0 / 4$ & $1 / 4$ & $0 / 2$ & $0 / 2$ & $0 / 2$ & $0 / 2$ & $\mathrm{~S}$ \\
\hline Willow tit Parus montanus Baldenstein & $2(2 / 0) / 4$ & $2(2 / 0) / 4$ & $0 / 4$ & $0 / 4$ & n.a. & n.a. & n.a. & n.a. & $\mathrm{S}$ \\
\hline Common magpie Pica pica (Linnaeus) & $1(0 / 1) / 7$ & $2(2 / 0) / 7$ & $0 / 7$ & $0 / 7$ & n.a. & n.a. & n.a. & n.a. & \\
\hline Hazelhen Tetrastes bonasia (Linnaeus) & $1(0 / 1) / 5$ & $0 / 5$ & $0 / 5$ & $0 / 5$ & n.a. & n.a. & n.a. & n.a. & $\mathrm{S}$ \\
\hline Thrush nightingale Luscinia luscinia (Linnaeus) & $1(0 / 1) / 1$ & $0 / 1$ & $0 / 1$ & $0 / 1$ & n.a. & n.a. & n.a. & n.a. & M, Africa \\
\hline Eurasian siskin Spinus spinus (Linnaeus) & $1(1 / 0) / 3$ & $0 / 3$ & $0 / 3$ & $0 / 3$ & $0 / 1$ & $0 / 1$ & $0 / 1$ & $0 / 1$ & S or M, Middle Asia \\
\hline $\begin{array}{l}\text { Greater spotted woodpecker } \\
\text { Dendrocopos major (Linnaeus) }\end{array}$ & $1(0 / 1) / 2$ & $0 / 2$ & $0 / 2$ & $0 / 2$ & $0 / 1$ & $0 / 1$ & $0 / 1$ & $0 / 1$ & $\mathrm{~S}$ \\
\hline Garden warbler Sylvia borin (Boddaert) & $0 / 5$ & $0 / 5$ & $0 / 5$ & $0 / 5$ & $0 / 3$ & $0 / 3$ & $1 / 3$ & $0 / 3$ & M, Africa \\
\hline Bluestart Tarsiger cyanurus (Pallas) & $0 / 2$ & $1(0 / 1) / 2$ & $0 / 2$ & $0 / 2$ & $0 / 2$ & $0 / 2$ & $0 / 2$ & $0 / 2$ & M, South-East Asia \\
\hline European wigeon Anas penelope Linnaeus & $0 / 5$ & $0 / 5$ & $1 / 5$ & $0 / 5$ & n.a. & n.a. & n.a. & n.a. & M, Europe, Kaspian and India \\
\hline Green-winged teal Anas crecca Linnaeus & $1(0 / 1) / 3$ & $0 / 3$ & $0 / 3$ & $0 / 3$ & n.a. & n.a. & n.a. & n.a. & M, India, Kaspian and Near East \\
\hline Common merganser Mergus merganser Linnaeus & $1(0 / 1) / 3$ & $0 / 3$ & $0 / 3$ & $0 / 3$ & n.a. & n.a. & n.a. & n.a. & M, Europe \\
\hline Waxwing Bombycilla garrulous (Linnaeus) & $1(1 / 0) / 1$ & $0 / 1$ & $0 / 1$ & $0 / 1$ & n.a. & n.a. & n.a. & n.a. & $\mathrm{S}$ or $\mathrm{M}$, India \\
\hline Coal tit Parus ater Linnaeus & $1(1 / 0) / 1$ & $0 / 1$ & $0 / 1$ & $0 / 1$ & n.a. & n.a. & n.a. & n.a. & $\mathrm{S}$ \\
\hline Spoonbill Anas clypeata Linnaeus & $1(1 / 0) / 3$ & $0 / 3$ & $0 / 3$ & $0 / 3$ & n.a. & n.a. & n.a. & n.a. & M, India, Europe and Kaspian \\
\hline
\end{tabular}

${ }^{a}$ Species are listed according to the number of revealed pathogens; ${ }^{\mathrm{b}}$ This species belongs to specific parasitic system including tick Ixodes lividus Koch, 1844 , inhabiting sand martins caves; ${ }^{\circ}$ not analyzed

roat). Comparison of the index of the abundance of ticks per bird among the different species of birds with the number of pathogens found in these species revealed that there were no statistically significant differences $(r=-0.05, \mathrm{P}<0.05)$. Moreover, considering the fieldfare as a basic feeder for ticks, we examined whether the number of pathogens was higher in individuals with several ticks. Our analysis within one species of birds revealed the same result, i.e., no relationship between the number of pathogens and the number of ticks per bird $(r=0.05, \mathrm{P}<0.05)$. However, the ticks collected from the birds that were in close contact with ticks were more often considered to be carriers of the pathogens than the ticks collected from the birds that served as secondary feeders, for example, the family Sylviidae.

\section{Comparison of infection markers in birds and ticks}

We revealed the tendency of simultaneous infections (coinfections) in birds and ticks. Coinfections (two to seven pathogens simultaneously in one bird) were highly common. Some individuals were positive for the markers from 
Table 3. Prevalence of pathogens (\%) in sedentary and migratory birds

\begin{tabular}{|c|c|c|c|c|c|c|c|c|}
\hline Group of birds & TBEV & WNV & Borrelia spp. & Rickettsia spp. & Bartonella spp. & Babesia spp. & Ehrlichia spp. & Anaplasma spp. \\
\hline Sedentary & $\begin{array}{l}37.7 \\
\mathrm{n}=61\end{array}$ & $\begin{array}{c}34.4 \\
\mathrm{n}=61\end{array}$ & $\begin{array}{c}1.63 \\
\mathrm{n}=61\end{array}$ & $\begin{array}{c}16.4 \\
n=61\end{array}$ & $\begin{array}{c}0.0 \\
\mathrm{n}=16\end{array}$ & $\begin{array}{c}12.5 \\
\mathrm{n}=16\end{array}$ & $\begin{array}{c}0 \\
\mathrm{n}=16\end{array}$ & $\begin{array}{c}25.0 \\
\mathrm{n}=16\end{array}$ \\
\hline Migrants & $\begin{array}{c}35.8 \\
\mathrm{n}=355\end{array}$ & $\begin{array}{c}25.4 \\
\mathrm{n}=355\end{array}$ & $\begin{array}{c}10.4 \\
\mathrm{n}=355\end{array}$ & $\begin{array}{c}10.1 \\
\mathrm{n}=355\end{array}$ & $\begin{array}{c}14.9 \\
\mathrm{n}=107\end{array}$ & $\begin{array}{c}10.3 \\
\mathrm{n}=107\end{array}$ & $\begin{array}{c}6.5 \\
\mathrm{n}=107\end{array}$ & $\begin{array}{c}11.2 \\
\mathrm{n}=107\end{array}$ \\
\hline $\begin{array}{l}F-\text { test } \\
\text { p-value }\end{array}$ & $\begin{array}{l}F=0.28 \\
P>0.05\end{array}$ & $\begin{array}{l}F=1.43 \\
P>0.05\end{array}$ & $\begin{array}{c}\mathrm{F}=2.89 * \\
\mathrm{P}<0.01\end{array}$ & $\begin{array}{l}F=1.34 \\
P>0.05\end{array}$ & $\begin{array}{c}\mathrm{F}=2.96^{*} \\
\mathrm{P}<0.01\end{array}$ & $\begin{array}{c}F=0.261 \\
P>0.05\end{array}$ & $\begin{array}{l}F=1.93 \\
P>0.05\end{array}$ & $\begin{array}{l}F=1.35 \\
P>0.05\end{array}$ \\
\hline
\end{tabular}

*Differences are statistically significant

four to seven infections. For instance, the fieldfare had four pathogens (WNV, Rickettsia spp., Babesia spp. and Ehrlichia spp.) and six pathogens (TBEV, Borrelia spp., Bartonella spp., Babesia spp., Ehrlichia spp. and Anaplasma spp.), the common chaffinch had four pathogens (TBEV, WNV, Borrelia spp. and Rickettsia spp.) and five pathogens (Borrelia spp., Batronella spp., Babesia spp., Ehrlichia spp. and Anaplasma spp.), and the common redstart had seven pathogens (all except WNV). We also found up to four infection markers in individual ticks.

In the present study, we focused on the comparison of pathogens in individual birds and the ticks that fed strictly on them.

As we had data on the pairwise comparison of infected birds and ticks captured from these individuals, we compared the number and composition of pathogens in these pairs $(n=45)$. Consequently, we identified several variants of pairwise combinations (Table 4) as follows:

- Birds had one or more markers of infections, but the ticks collected from these birds were free of pathogens $(53.3 \%)$.

- Infections in birds were not found, but the ticks collected from them had one infection agent (11.1\%).

- Complete match by the type of pathogens was observed in the infected birds and the ticks collected from them (8.9\% of cases).

- Both birds and ticks were infected by one to four pathogens, one or more of them being the same. In general, a partial match was detected in $15.6 \%$ of cases.

- Birds and ticks contain different infections, and their mismatch was observed in $11.1 \%$ of cases.

\section{DISCUSSION}

Of the 43 species of birds examined in the Tomsk region in which the pathogens were identified, the proportions of birds associated with wintering in different regions were as follows: $23.3 \%$ in Europe, $25.6 \%$ in India, $18.6 \%$ in Africa, $16.3 \%$ in the Caspian and the Middle East, 9.3\% in Southeast Asia, and 6.9\% in Central Asia, and 32.6\% of birds were sedentary. It is certain that the emergence of the Far Eastern strain of TBEV, as well as WNV and the tick Ixodes pavlovskyi, in our region was directly caused by birds (Ternovoi et al. 2004, Mikryukova et al. 2014, Moskvitina et al. 2014). Similarly, owing to birds, the tick Hyalomma marginatum Koch, 1844 has extended its habitat range in Europe, potentially spreading the pathogens associated with it (Poupon et al. 2006, Molin et al. 2011, Diakou et al. 2016, Klaus et al. 2016). This tick was found on the migrating birds Phoenicurus phoenicurus (Linnaeus) and Anthus trivialis (Linnaeus) in the westernmost re- gion of Russia, i.e., the Kaliningrad region, where one of the ticks was found to have an exotic species, Rickettsia aeshlimannii (see Movila et al. 2013). We can expect the discovery of the same species of pathogens that have been identified in the wintering areas of our birds (Cazorla et al. 2008, Tonetti et al. 2009, Ghosh and Nagar 2014, Sparagano et al. 2015, Yang et al. 2015, Kuo et al. 2017).

It is obvious that birds often attacked by ticks, primarily those from the family Turdidae, play an important role in maintaining the foci of natural infections. This was confirmed by the number of infected ticks that were more common on ground-foraging birds, which are the major tick hosts. A correlational analysis between the number of pathogens detected in birds and the number of ticks parasitising on them revealed that the number of pathogens was equal in birds with frequent and rare contact with ticks. On the one hand, it was logical to assume that the more often the ticks attack, the more infections the birds have. In contrast, we may expect the result indicating that more frequent attacks by ticks lead to fewer pathogens. The latter result may be associated with the formation of immune mechanisms of pathogen suppression during prolonged and/or multiple parasitisation of ticks, as demonstrated in several studies (Wakelin 1996, Wikel et al. 1997, Kislenko and Korotkov 1998, Heylen et al. 2010).

The finding that the number of pathogens in birds did not directly depend on the number of parasitic ticks can be explained by the fact that the birds get infected over a long period, and thus the number of pathogens does not necessarily depend on the number of ticks found on them at the time of capture.

Quite unexpectedly, we found a significant number of birds $(32.9 \%)$ with WNV markers far from the territories endemic for this infection. Furthermore, the obtained indicator of prevalence significantly exceeded that in several other regions (Balança et al. 2009, Jourdain et al. 2011, López et al. 2011, Murata et al. 2011, Czank et al. 2016). The prevalence of infections in different species of ticks by WNV markers also confirmed to be quite high at 3.4$5.1 \%$. In contrast, in Italy and Greece, which are located closer to the areas of WNV distribution, this virus was not detected in ticks parasitising on migratory birds (Hagman et al. 2014).

The suggestion that tropical arboviruses can be disseminated and settled in temperate latitudes in ticks was made more than 30 years ago (Nekipelov 1978). Despite the fact that WNV is traditionally considered as a mosquito infection, it is known that argasid and ixodid ticks can be involved in the circulation of this pathogen (Mumcuoglu 2005, Reiter 2010). In some cases, in the absence of mosquitoes, circu- 
Table 4. Comparison of infection markers in wild birds and attached ticks

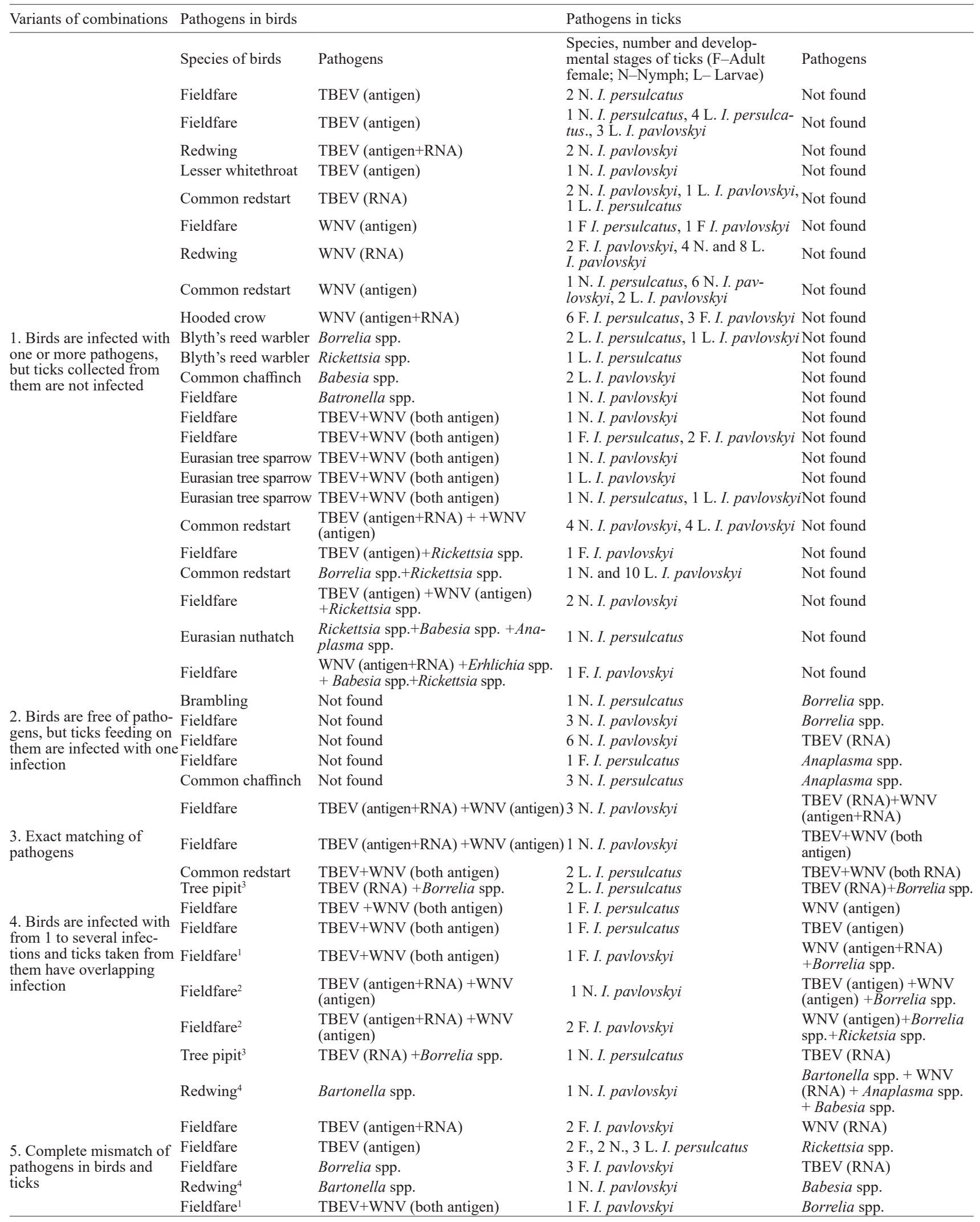

${ }^{1-4}$ Birds under the same number represent the same individual

lation occurs exclusively owing to ticks (Lvov and Il'ichev 1979). In Russia, several WNV strains were isolated from ticks (Platonov 2001), although these strains were less dangerous for vertebrates (Lvov et al. 2004).
On the basis of the above-described data, WNV can persist and winter in ticks, thereby hypothetically supporting its circulation in nature. This scenario is probably in action in our research area. Earlier, WNV was found here in 
questing adult ticks that were sampled using a flag. Moreover, it was found in small mammals and birds and the subadult ticks that fed on them (Moskvitina et al. 2008). The transmission of this infection by ticks was confirmed by WNV markers (antigens and RT-PCR detection) in sedentary birds (great tit, hooded crow, Eurasian nuthatch, common bullfinch, and willow tit) and in ticks collected from them. WNV was found in sedentary birds as frequently as in migratory birds. WNV was also detected in the nestlings of migratory birds that had never migrated yet. Furthermore, the highest rate of infection by WNV was exhibited by the great tit, the sedentary or vagrant bird, which does not migrate to WNV-endemic areas (Fig. 2). The second most infected bird was the hooded crow, the bird belonging to the family Corvidae and well-known as a WNV reservoir (Eidson et al. 2001).

Notwithstanding that several facts indicate that ticks are involved in the transmission of WNV, the level of viremia in birds after a tick bite remains unknown. Attempts to isolate WNV from ticks and bird organs have been unsuccessful, although this was possible for TBEV (Mikryukova et al. 2014). According to experimental data (Ciota et al. 2015), WNV in the tick cell line culture underwent genetic modification and actually became unable to infect vertebrates. However, there are contrasting data that have been obtained experimentally (Azarova and Mishaeva 2002). The authors confirmed in the laboratory the transmission of WNV from infected mice to uninfected ticks (Ixodes rici$n u s$ ) and from infected ticks to uninfected mice through the developmental stages of ticks and the transovarial transfer of pathogen with titres sufficient for circulation.

Therefore, laboratory experiments confirm the possibility of the participation of ticks of the genus Ixodes in the circulation of the virus. However, the question of the participation of ticks in the transmission of WNV in nature remains open. We cannot deny that some birds could be infected in wintering areas and through mosquito bites, especially considering the duration of WNV viremia in birds (Wheeler 2012).

The data obtained in the present study on the infection of birds and ticks by various pathogens have similarities with both different territories and their regional specificities. Hence, the presence of Borrelia spp. in ticks collected from birds in Western Siberia (Moskvitina et al. 2014) confirmed to be quite similar to that found in some countries of Europe such as Germany (Franke et al. 2010), Czech Republic (Dubska et al. 2011), Latvia (Capligina et al. 2014), Switzerland (Lommano et al. 2014), but it was lower than that in Italy (Toma et al. 2014), Great Britain (Kurtenbach et al. 1998), the USA (Hamer et al. 2012), and the western part of Russia (Alekseev et al. 2001).

The prevalence of tick infection with Rickettsia spp. was lower than that in the majority of studies (Špitalská et al. 2011, Hornok et al. 2014, Toma et al. 2014, Diakou et al. 2016), and that of Ehrlichia spp. was also lower (Alekseev et al. 2001, Toma et al. 2014). At the same time, the level of infection was higher than that reported in several studies on Bartonella spp. (Molin et al. 2011, Movila et al.
2014) and on Anaplasma spp. (Dubska et al. 2012, Palomar et al. 2012, Geller et al. 2013, Lommano et al. 2014).

Most of the studies conducted in recent years were aimed primarily at identifying pathogens in ticks collected from birds, with the results being considered a priori as facts confirming the circulation of certain infections in ticks and birds (Dubska et al. 2012, Capligina et al. 2014, Lommano et al. 2014, Michelet et al. 2016). In our opinion, the detection of pathogens only in ticks found on some species of birds, without identifying the pathogens in the bird itself, cannot be unequivocal evidence of the role of birds in the circulation of pathogens.

For instance, in several studies, the great tit was reported as a carrier of ticks infected with Borrelia spp. (Comstedt et al. 2006, Dubska et al. 2009, Geller et al. 2013, Heylen et al 2013, Hornok et al. 2013), as well as with Anaplasma spp. (Špitalská et al. 2011) and Babesia spp. (Hildebrandt et al. 2010). However, none of the birds of this species we analysed exhibited markers of these pathogens. On the one hand, this may be a random coincidence or regional specificity, because the great tit in our biotopes is not often infected with ticks. At the same time, as mentioned earlier, the great tit ranked the topmost in terms of the level of infection with WNV and TBEV and was also a carrier of Rickettsia spp. The latter finding corresponds to the fact that ticks in the great tit were infected by this species of pathogen as reported in several studies (Hildebrandt et al. 2010, Movila et al. 2011, Špitalská et al. 2011, Hornok et al. 2013).

A similar situation was observed with the redwing, one of the important tick hosts. Like the great tit, several authors have mentioned it as a carrier of ticks infected with Anaplasma spp., Babesia spp., and Borrelia spp. (Olsén 1995, Comstedt et al. 2006, Geller et al. 2013, Capligina et al. 2014). Our studies did not identify infection by these pathogens in the birds themselves. At the same time, this species was again a carrier of WNV, TBEV, Rickettsia spp., and Bartonella spp. The absence of Borrelia spp. is perhaps accidental, because a species similar to the redwing, the fieldfare, was infected with all pathogens. These results illustrate the need to evaluate the infection of not only the ticks that feed on birds but also the birds themselves, as the role of the latter may not coincide with their role assumed solely on the basis of the presence of infected ticks.

In recent years, several studies have analysed the infection of the birds themselves (de la Fuente et al. 2005, Stańczak et al. 2009, Yang et al. 2015, Ebani et al. 2016), including the infection of birds and their ectoparasites (Norte et al. 2013, Hornok et al. 2014, Sándor et al. 2016).

These studies show both cases of coincidence and mismatch of pathogens between birds and ticks parasitising on them, which confirms the need to analyse the infection with pathogens in the bird-tick system, because this allows us to better understand the mechanism of pathogen circulation in ecosystems.

Our pairwise comparisons of pathogens in birds and ticks showed that in $75.5 \%$ of cases, there were discrepancies in the identified pathogens. One of the reasons was that the exchange of pathogens between birds and ticks had 
not occurred yet. On the other hand, there is a possibility of some barriers in the tick-bird system that prevents the transmission of pathogens. Therefore, some researchers (Alekseev and Dubinina 2007) have put forward an idea of the antagonistic relationship between pathogens, which prevents their coexistence in the same tick or vertebrate. However, from these viewpoints, it is impossible to explain the presence of mixed infections in birds if, for example, four to seven pathogens in one bird or four pathogens in one tick are detected.

Hence, the redstart had seven pathogens, except for WNV; one nymph of I. pavlovskyi collected from a redwing had WNV, Babesia spp., Bartonella spp., and Anaplasma spp., whereas the redwing itself was infected with Bartonella spp. The latter fact indicates the possible involvement of birds in the circulation of Bartonella spp.

Borrelia spp. can also be used to illustrate a different spectrum of variants of infection with this pathogen in the bird-tick system with the participation of various bird species (Table 4). Therefore, the garden warbler was infected with Borrelia spp., whereas the ticks on it were free of pathogens. The common redstart was infected with Borrelia spp. and Rickettsia spp., whereas the ticks were uninfected. In contrast, two cases, a brambling and a fieldfare that were free of pathogens, were carriers of nymphs infected with Borrelia spp. There was a case of a fieldfare infected with Borrelia spp., and three adult ticks (females) on it were infected with TBEV. In two fieldfares infected with TBEV + WNV, the ticks were infected with, apart from viruses, Borrelia spp.; in one of these birds, the tick was infected only with Borrelia spp. This finding may indicate either the trans-stadial transmission of Borrelia spp. by these ticks or that cofeeding with bacteremia has not yet begun in these birds.

Finally, a case was observed when in a tree pipit infected with TBEV + WNV + Borrelia spp., one nymph with TBEV and two larvae infected with TBEV + Borrelia spp. were found, which confirmed the transmission of this pathogen in the bird-tick system.

Of all cases of pairwise-compared infections in the bird-tick system, we detected a coincidence indicating the possibility of transmission for four pathogens, the above-mentioned Bartonella spp. and Borrelia spp. as well as TBEV and WNV. The coincidence of infections in the bird-tick system was not detected for Ehrlichia spp., Babesia spp., Anaplasma spp., and Rickettsia spp., although all these pathogens were found in birds and ticks separately.

Although a study by Sándor et al. (2016) provides evidence of infection in birds and ticks with Anaplasma spp. and Rickettsia spp., it is not clear whether the infected ticks were found on the infected birds. The study conducted by Hornok et al. (2014) reported examples of synchronous infection with Rickettsia spp. of birds and ticks collected from them, which confirms the transmission of this bacterium, and there is also evidence of mismatch in birds and ticks infected with Anaplasma spp. However, it is believed that birds play an important role in maintaining Anaplasma spp. (de la Fuente et al. 2005, Ioannou et al. 2009, Franke et al. 2010).
Regarding Babesia spp., no consensus exists on the role of birds in the circulation of these pathogens. We detected markers of this infection in $13 \%(13 / 109)$ of birds, as well as in two ticks collected from an uninfected bird, which may indicate a possible transmission through the cofeeding mechanism. The same possibility has been suggested previously (Kuo et al. 2017). However, in another study (Yabsley et al. 2013), it was observed that birds are an unlikely reservoir of Babesia spp.

On the basis of the data of the synchronous infection of birds and ticks, we attempted to understand the relationship in the tick-bird-pathogen system. The presence of the pathogen in birds and ticks may indirectly indicate a possible transmission of infection, but the level of bacteremia and viremia in birds and ticks may not be sufficient to transmit the infection. Considering the facts we have disclosed about a high proportion of mismatches in pathogen species between birds and ticks parasitising on them, it can be assumed that the relationships between the components of the parasitic bird-tick-pathogen system are not so straightforward, depend on the multiplicity of manifestations of these connections, and require more in-depth research.

On the basis of our study results, the following conclusions can be made:

1. In 43 species of birds, one to eight infection agents transmitted through tick bites were detected. Comparison of the number of infected birds among migratory and sedentary species did not reveal significant differences between them in the prevalence of pathogens. This finding may indicate that most of the pathogens could have been transmitted through tick bites at our research sites, rather than being introduced from outside.

2. Different species of birds exhibited differences in the prevalence of pathogens, in particular viral infections (TBEV and WNV). For example, the highest prevalence of WNV infection was found in the sedentary hooded crow Corvus cornix and the great tit Parus major. Although the former species is known as a typical natural reservoir of $\mathrm{WNV}$, the great tit probably proved to be nonspecific, but susceptible, to the pathogen species of birds.

3. The number of detected pathogens in birds on which ticks frequently feed did not differ from that in birds that have rare contact with ticks. In addition, the number of pathogens in individual birds did not correlate with the number of ticks parasitising on them.

4. Despite the significant prevalence of infection markers in birds and ticks, the pairwise infection comparison analysis in birds and ticks showed that complete or partial coincidence of infection markers was observed in only $24.5 \%$ of cases. It was observed for TBEV, WNV, Borrelia spp. and Bartonella spp. We are forced to admit and emphasise that this are only preliminary data because the most of pathogens were identified only up to genus level. Viruses (TBEV and WNV), as well as the combination of TBEV and Borrelia spp., were the most frequently cooccurring pathogens. 
Authors' contribution. Igor G. Korobitsyn wrote the manuscript, supervised ornithological work, data analysis. Nina S. Moskvitina initiated and supervised the study, critically revised the manuscript. Oleg Yu. Tyutenkov mist-netted birds and collected ticks, data analysis. Sergey I. Gashkov mist-netted birds and collected ticks. Yulia V. Kononova detected pathogens in ticks and birds by IEA, data analysis. Sergey S. Moskvitin mist-netted birds and collected ticks. Vladimir N. Romanenko identified ticks based on morphology. Tamara P. Mikryukova performed the molecular analyses. Elena V. Protopopova performed the molecular analyses. Mikhail Yu. Kartashov detected pathogens in ticks. Evgeny V. Chausov detected pathogens in ticks. Svetlana N. Konovalova detected pathogens in ticks. Natalia L. Tupota detected pathogens in ticks. Alexandra O. Sementsova detected pathogens in ticks. Vladimir A. Ternovoi performed the molecular analyses. Valery B. Loktev supervised parasitological and microbiological work

Acknowledgments. The microbiological part of the research was supported by the Ministry of Science and Higher Education of the Russian Federation (Agreement No. 075-15-2019-1665). Zoological part of this study was supported by state assignment of the Ministry of Science and Higher Education of the Russian Federation, grant No. 0721-2020-0019.

\section{REFERENCES}

Alekseev A.N., Dubinina E.V. 2007: [Tick-borne encephalitis virus in the internal environment of the tick-vector: ecological aspects]. Bull. Sib. Branch Russian Acad. ScI. 4: 100-104. (In Russian.)

Alekseev A.N., Dubinina H.V., Semenov A.V., Bolshakov C.V. 2001: Evidence of ehrlichiosis agents found in ticks (Acari: Ixodidae) collected from migratory birds. J. Med. Entomol. 38: 471-474.

Azarova I.A., Mishaeva N.P. 2002: [Consistent patterns of circulation of the West Nile virus in the tick-vertebrate parasitic system and the factors affecting the pathogen reproduction and dissemination.] In: N.N. Maksimiuk, A.K. Yuzbekov, V.G. Fedorova (Eds.), Ecology, Biodiversity and Role of Blood Sucking Insects and Ticks in the Ecosystems of Russia. Proc. II Resp. ScI. Conf. V. Novgorod, 27-29 May 2002, pp. 128-133. (In Russian.)

Balança G., Gaidet N., Savini G., Vollot B., Foucart A. Reiter P., Boutonnier A., Lelli R., Monicat F. 2009: Low West Nile virus circulation in wild birds in an area of recurring outbreaks in southern France. Vector Borne Zoonotic Dis. 9: 737-741.

Capligina V., Salmane I., Keišs O., Vilks K., Japina K., BauMANiSA V., RANKa R. 2014: Prevalence of tick-borne pathogens in ticks collected from migratory birds in Latvia. Ticks Tick Borne Dis. 5: 75-81.

Cazorla C., Socolovschi C., Jensenius M., Parola P. 2008 : Tick-borne diseases: tick-borne spotted fever rickettsioses in Africa. Infect. Dis. Clin. N. Am. 22: 531-544.

Chausov E.V., Protopopova E.V., Konovalova S.N., Kononova Yu.V., Pershikova N. L., Moskvitina N.S., Romanenko V.N., Ivanova N.V., Bolshakova N.P., Moskvitin S.S., Korobitsyn I.G., Gashkov S.I., Tiutenkov O.Yu., Kuranova V.N., Kravchenko L.B., Suchkova N.G., Agulova L.P., LOKTEV V.B. 2010: Genetic diversity of tick-borne pathogenes in Tomsk and environs. Entomol. Rev. 90: 240-250.

Ciota A.T., Payne A.F., Kramer L.D. 2015: West Nile virus adaptation to ixodid tick cells is associated with phenotypic tradeoffs in primary hosts. Virology 482: 128-132.

Comstedt P., Bergström S., Olsen B., Garpmo U., Marjavaara L., Mejlon H., Barbour A.G., Bunikis J. 2006: Migratory passerine birds as reservoirs of Lyme borreliosis in Europe. Emerg. Infect. Dis. 12: 1087-1095.

Czank T., Bhide K., Bencúrová E., Dolinská S., Drzewniková P., Major P., Korytár L., Bocková E., Bhide M., Pistl J. 2016: Detection of West Nile virus and tick-borne encephalitis virus in birds in Slovakia, using a universal primer set. Arch. Virol. 161: 1679-1683.

Diakou A., Norte A.C., Lopes de Carvalho I., Núncio S., Nováková M., Kautman M., Alivizatos H., Kazantzidis S., Sychra O., Literák I. 2016: Ticks and tick-borne pathogens in wild birds in Greece. Parasitol. Res. 115: 2011-2016.
Dubska L., Literak I., Kocianova E., Taragelova V., Sverakova V., Sychra O., Hromadko M. 2011: Synanthropic birds influence the distribution of Borrelia species: analysis of Ixodes ricinus ticks feeding on passerine birds. Appl. Environ. Microbiol. 77: 1115-1117.

Dubska L., Literak I., Kocianova E., Taragelova V., Sychra O. 2009: Differential role of passerine birds in distribution of Borrelia spirochetes, based on data from ticks collected from birds during the postbreeding migration period in Central Europe. Appl. Environ. Microbiol. 75: 596-602.

Dubska L., Literak I., Kverek P., Roubalova E., KocianoVA E., Taragelova V. 2012: Tick-borne zoonotic pathogens in ticks feeding on the common nightingale including a novel strain of Rickettsia sp. Ticks Tick Borne Dis. 3: 265-268.

Ebani V.V., Bertelloni F., Mani P. 2016: Molecular survey on zoonotic tick-borne bacteria and chlamydiae in feral pigeons (Columba livia domestica). Asian Pac. J. Trop. Med. 9: 324-327.

Eidson M., Komar N., Sorhage F., Nelson R., Talbot T., Mostashari F., McLean R., Stone W., Anand M., Fine A., Jeffery N., Huang A., Falco C., Kopian S., Bradley C., Schmit K., Willsey A., Hagiwara Y., White D., Wallace B., Smith P., Chang H.-G., Bresnitz E., Campbell C., Roscoe D., Andreadis T., Anderson J., Vossbrinck C., Hadler J., Van Kruiningen H., Garmendia A., French R., Dickson J., Sileo L., Kerst A., Lanciotti R., Panella N.A. 2001: Dead crow densities and human cases of West Nile virus, New York State, 2000. Emerg. Infect. Dis. 7: 662-664.

Filippova N.A. 1977: [Ixodid Ticks (Ixodinae)]. Nauka Publ. House, Leningrad, 396 pp. (In Russian.)

Franke J., Moldenhauer A., Hildebrandt A., Dorn W. 2010: Are birds reservoir hosts for Borrelia afzelii? Ticks Tick Borne Dis. 1: 109-112.

de la Fuente J., Naranjo V., Ruiz-Fons F., Höfle U., Fernández de Mera I.G., Villanúa D., Almazán C., Torina A., Caracappa S., Kocan K.M., Gortázar C. 2005: Potential vertebrate reservoir hosts and invertebrate vectors of Anaplasma marginale and A. phagocytophilum in central Spain. Vector Borne Zoonotic Dis. 5: 390-401.

Geller J., Nazarova L., Katargina O., Leivits A., Järvekülg L., Golovljova I. 2013: Tick-borne pathogens in ticks feeding on migratory passerines in western part of Estonia. Vector Borne Zoonotic Dis. 13: 443-448.

Ghosh S., Nagar G. 2014: Problem of ticks and tick-borne diseases in India with special emphasis on progress in tick control research: a review. J. Vector Borne Dis. 51: 259-270.

Hagman K., Barboutis C., Ehrenborg C., Fransson T., Jaenson T., Lindgren P-E., Lundkvist A., Nyström F., Waldenström J., SAlaneck E. 2014: On the potential roles of ticks and migrating birds in the ecology of West Nile virus. Inf. Ecol. Epidemiol. 4: 20943.

Hamer S.A., Lehrer E., Magle S.B. 2012: Wild birds as sentinels for multiple zoonotic pathogens along an urban to rural 
gradient in Greater Chicago, Illinois. Zoonoses Publ. Hlth. 59: $355-364$.

HASLE G. 2013: Transport of ixodid ticks and tick-borne pathogens by migratory birds. Front. Cell. Infect. Microbiol. 3: 48.

Heylen D.J.A., Madder M., Matthysen E. 2010: Lack of resistance against the tick Ixodes ricinus in two related passerine bird species. Int. J. Parasitol. 40: 183-191.

Heylen D., Tijsse E., Fonville M., Matthysen E., Sprong H. 2013: Transmission dynamics of Borrelia burgdorferi s.1. in a bird tick community. Environ. Microbiol. 15: 663-673

Hildebrandt A., Franke J., Meier F., Sachse S., Dorn W., Straube E. 2010: The potential role of migratory birds in transmission cycles of Babesia spp., Anaplasma phagocytophilum, and Rickettsia spp. Ticks Tick Borne Dis. 1: 105-107.

Hornok S., Csörgö T., de la Fuente J., Gyuranecz M., Privigyei C., Meli M.L., Kreizinger Z., Gönczi E., Fernández de Mera I.G., Hofmann-Lehmann R. 2013: Synanthropic birds associated with high prevalence of tick-borne Rickettsiae and with the first detection of Rickettsia aeschlimannii in Hungary. Vector Borne Zoonotic Dis. 13: 77-83.

Hornok S., Kováts D., Csörgö T., Meli M.L., Gönczi E., Hadnagy Z., Takács N., Farkas R., Hofmann-LehmanN R. 2014: Birds as potential reservoirs of tick-borne pathogens: first evidence of bacteraemia with Rickettsia helvetica. Parasit. Vectors 7: 128.

HubÁLEK Z. 2004: An annotated checklist of pathogenic microorganisms associated with migratory birds. J. Wildl. Dis. 40: 639-659.

Ioannou I., Chochlakis D., Kasinis N., Anayiotos P., LysSandrou A., Papadopoulos B., Tselentis Y., PsaroulaKI A. 2009: Carriage of Rickettsia spp., Coxiella burnetii and Anaplasma spp. by endemic and migratory wild birds and their ectoparasites in Cyprus. Clin. Microbiol. Infect. 15: 158-160.

Jourdain E., Olsen B., Lundkvist A., Hubálek Z., Šikutová S., Waldenström J., Karlsson M., Wahlström M., Jozan M., FALK K.I. 2011: Surveillance for West Nile virus in wild birds from northern Europe. Vector Borne Zoonotic Dis. 11: $77-79$.

Kang J.-G., Kim H.-C., Choi C.-Y., Nam H.-Y., Chae H.-Y., Chong S.-T., Klein T.A., Ko S., Chae J.-S. 2013: Molecular detection of Anaplasma, Bartonella, and Borrelia species in ticks collected from migratory birds from Hong-do Island, Republic of Korea. Vector Borne Zoonotic Dis. 4: 215-225.

Kartashov M.Y., Kononova Y.V., Petrova I.D., Tupota N.L., Mikryukova T.P., Ternovoi V.A., Tishkova F.H., Loktev V.B. 2020: Detection of Ehrlichia spp. and Theileria spp. in Hyalomma anatolicum ticks collected in Tajikistan. Vavilovskii Zh. Genet. Selektsii 24: 55-59.

Kartashov M.Y., Mikryukova T.P., Moskvitina N.S., Krivosheina E.I., KuZnetsov A.I., Romanenko V.N., Bol'shakova N.P., Ternovoi V.A., Loktev V.B. 2019: [Detection and genotyping of Anaplasma phagocytophilum in I. persulcatus and D. reticulatus ticks collected in Tomsk (Western Siberia) in 2015-2016.] Bull. Siberian Med. 18: 89-98. (In Russian.)

KisLenko G.S., Korot Kov Y.S. 1998: [On existence of functional relationship between the index of larva and nymph abundance in a virus carrier and the quantity immunity to infectious stimulus in small rodents from natural locus of tick-borne encephalitis]. Zool. Zh. 77: 504-506. (In Russian.)

Klaus C., Gethmann J., Hoffmann B., Ziegler U., Heller M., Beer M. 2016: Tick infestation in birds and prevalence of pathogens in ticks collected from different places in Germany. Parasitol. Res. 115: 2729-2740.

Kuo C.-C., Lin Y.-F., Yao C.-T., Shih H.-C., Chung L.-H., LiaO H.-C., Hsu Y.-C., Wang H.-C. 2017: Tick-borne pathogens in ticks collected from birds in Taiwan. Parasit. Vectors 10: 587.

Kurtenbach K., Peacey M., Rijpkema S.G.T., Hoodless A.N., Nuttall P.A., RandolPh S.E. 1998: Differential transmis- sion of the genospecies of Borrelia burgdorferi sensu lato by game birds and small rodents in England. Appl. Environ. Microbiol. 64: 1169-1174.

Lommano E., Dvořák C., Vallotton L., Jenni L., Gern L. 2014: Tick-borne pathogens in ticks collected from breeding and migratory birds in Switzerland. Ticks Tick Borne Dis. 5: $871-882$.

López G., Jiménez-Clavero M.Á., Vázquez A., Soriguer R., Gómez-Tejedor C., Tenorio A., Figuerola J. 2011: Incidence of West Nile virus in birds arriving in wildlife rehabilitation centers in southern Spain. Vector Borne Zoonotic Dis. 11: $285-290$.

Lvov D.K., IL'ICHev V.D. 1979: [Migration of Birds and Transmission of Pathogens of Infections. Ecological and Geographical Relations of Birds with Pathogens of Infections]. Nauka, Moscow, 271 pp. (In Russian.)

Lvov D.K., Kovtunov A.I., Yashinulov K.B., Gromashevsky V.L., DJarkenov A.F., ShChelkanov M.Yu., Kulikova L.N., Savidge G., Chimidova N.M., Mikhalyayeva L.B., Vasilyev A.V., Galkina I.V., Prilipov A.G., Kinni R., Samokhvalov E.I., Bushkiyeva B. Ts., Gubler D., AlKhovsky S.V., Aristova V.A., Deryabin P.G., Butenko A.M., Moskvina T.M., Lvov D.N., Zlobina L.V., Lyapina O.V., Sadykova G.K., Shatalov A.G., Usachyov V.E., VoRONINA A.G., LunYova L.I. 2004: [The specificity of circulation of West Nile Virus (Flaviviridae, Flavivirus) and of some other arboviruses in the ecosystems of Volga delta, Volga-Akhtuba flood-lands and adjoining arid regions (2000-2002)]. Vopr. Virusol. 49: 45-52. (In Russian.)

Michelet L., Joncour G., Devillers E. Torina A., Vayssier-Taussat M., Bonnet S.I., Moutailler S. 2016: Tick species, tick-borne pathogens and symbionts in an insular environment off the coast of Western France. Ticks Tick Borne Dis. 7: 1109-1115.

Mikryukova T.P., Moskvitina N.S., Kononova Yu.V., Korobitsyn I.G., Kartashov M.Y., TYuten'Kov O.Y., Protopopova E.V., Romanenko V.N., Chausov E.V., Gashkov S.I., Konovalova S.N., Moskvitin S.S., Tupota N.L., Sementsova A.O., Ternovoi V.A., Loktev V.B. 2014: Surveillance of tick-borne encephalitis virus in wild birds and ticks in Tomsk City and its suburbs (Western Siberia). Ticks Tick Borne Dis. 5: 145-151.

Molin Y., Lindeborg M., Nyström F., Madder M., Huelm E., Olsen B., Jaenson T.G.T., Ehrenborg C. 2011: Migratory birds, ticks, and Bartonella. Inf. Ecol. Epidemiol. 1: 5997.

Mosk Vitin S.S. 1992: [Wintering of birds of the Tomsk region and the issue of managing their populations]. In: V.P. Parnachov (Ed.), Problems of Ecology of the Tomsk Region. Vol. I. Tomsk State University, Tomsk, pp. 104-106. (In Russian.)

Moskvitin S.S., DuboviK A.D. 1969: [About the migration of birds of Tomsk region according to the banding]. In: V.P. Parnachov (Ed.), Migratory Birds and Their Role in Spreading Arboviruses. Nauka, Novosibirsk, pp. 50-55. (In Russian.)

Moskvitin S.S., Dubovik A.D. 1977: [About the migration of birds of Tomsk region according to the banding data (message 2)]. In: V.A. Pegel (Ed.), Proceedings of Research of the Institute of Biology and Biophysics, Tomsk State University. Publishing House of Tomsk State University, Tomsk, pp. 6-10. (In Russian.)

Moskvitin S.S., Strelkov V.E. 1977: [About the bird migration in Tomsk region according to the banding]. In: K.T. Yurlov (Ed.), Bird Migration in Asia. Nauka, Novosibirsk, pp. 101-107. (In Russian.)

Moskvitina N.S., Korobitsyn I.G., Tutenkov O.Yu., Gashkov S.I., Kononova Yu.V., Moskvitin S.S., Romanenko V.N., Mikryukova T.P., Protopopova E.V., Kartashov M.Yu., Chausov E.V., Konovalova S.N., Tupota N.L., Sementsova A.O., Ternovoy V.A., Loktev V.B. 2014: The role of birds in the maintenance of tick borne infections in the Tomsk anthropourgic foci. Biol. Bull. 4: 387-393. 
Moskvitina N.S., Romanenko V.N., Ternovoi V.A., Ivanova N.V., Protopopova E.V., Kravchenko L.B., Kononova Iu.V., Kuranova V.N., Chausov E.V., Moskvitin S.S., PerShikova N.L., Gashkov S.I., Konovalova S.N., Bol'shaKova N.P., LokTev V.B. 2008: [Detection of the West Nile virus and its genetic typing in ixodid ticks (Parasitiformes: Ixodidae) in Tomsk City and its suburbs]. Parazitologiya 42: 210-225. (In Russian.)

Movila A., Alekseev A.N., Dubinina H.V. Toderas I. 2013: Detection of tick-borne pathogens in ticks from migratory birds in the Baltic region of Russia. Med. Vet. Entomol. 27: 113-117.

Movila A., Dubinina H.V., Sitnicova N., Bespyatova L., Uspenskaia I., Efremova G., Toderas I., Alekseev A.N. 2014: Comparison of tick-borne microorganism communities in Ixodes spp. of the Ixodes ricinus species complex at distinct geographical regions. Exp. Appl. Acarol. 63: 65-76.

Movila A., Reye A.L, Dubinina H.V., Tolstenkov O.O., Toderas I., Hubschen J.M., Muller C.P., Alekseev A.N. 2011: Detection of Babesia sp. EU1 and members of spotted fever group Rickettsiae in ticks collected from migratory birds at $\mathrm{Cu}$ ronian Spit, North-Western Russia. Vector Borne Zoonotic Dis. 11: 89-91.

Mumcuoglu K.Y., Banet-Noach C., Malkinson M., Shalom U., Galun R. 2005: Argasid ticks as possible vectors of West Nile virus in Israel. Vector Borne Zoonotic Dis. 5: 65-71.

Murata R., Hashiguchi K., Yoshit K., Kariwa H., Nakajima K., Ivanov L.I., Leonova G.N., Takashima, I. 2011: Seroprevalence of West Nile virus in wild birds in Far Eastern Russia using a focus reduction neutralization test. Am. J. Trop. Med. Hyg. 84: 461-465.

Nekipelov N.V. 1978: [On possibility of introgression of arboviruses, brought by migratory birds from southern latitude.] In: A.I. Cherepanov (Ed.), Transcontinental Connections of Migratory Birds and Their Roles in the Dispersal of Arboviruses. Nauka, Novosibirsk, pp. 150-152. (In Russian.)

Norte A.C., Ramos J. A., Gern L., Núncio M.S., Lopes de CARvalho I. 2013: Birds as reservoirs for Borrelia burgdorferi s.l. in Western Europe: circulation of B. turdi and other genospecies in bird-tick cycles in Portugal. Environ. Microbiol. 15: 386-397.

Olsén B., Jaenson T.G.T., Bergrström S. 1995: Prevalence of Borrelia burgdorferi sensu lato-infected ticks on migrating birds. Appl. Environ. Microbiol. 61: 3082-3087.

Palomar A.M., Santibáñez P., Mazuelas D., Roncero L., Santibáñez S., Portillo A., Oteo J. 2012: Role of birds in dispersal of etiologic agents of tick-borne zoonoses, Spain, 2009. Emerg. Inf. Dis. 18: 1188-1191.

Pankina T.M., Poltoratskaya N.V., Istratkina S.V., Poltoratskaya T.N., Shikhin A.V. 2015: [Modern epidemiology of infections transmitted by ticks (Parasitiformes, Ixodidae) in the Tomsk region.] In: V. Romanenko, Y. Maximova, R. Bagirov, E. Subbotina (Eds.), Conceptual and Applied Aspects of Scientific Research and Education in the Field of Invertebrate Zoology. Tomsk State University, Tomsk, pp. 200-205. (In Russian.)

Platonov A.E. 2001: West Nile encephalitis in Russia 1999-2001: were we ready? Are we ready? Ann. N.Y. Acad. ScI. 951: 102-116.

Ponomareva E.P., Ternovoi V.A., Mikryukova T.P., Protopopova E.V., Tupota N.L., Loktev V.B. 2021. Genetic variability of 5'-untraslated region of the tick-borne encephalitis virus genome in various regions of northern Eurasia. Mol. Biol. 55: 431-440. (In Russian.)

Poupon M.-A., Lomanno E., Humair P.-F., Douet V., Rais O., SchaAd M., Lukas J., Gern L. 2006: Prevalence of Borrelia burgdorferi sensu lato in ticks collected from migratory birds in Switzerland. Appl. Environ. Microbiol. 72: 976-979.

Rar V.A., Fomenko N.V., Dobrotvorsky A.K., Livanova N.N., Rudakova S.A., Fedorov E.G., Astanin V.B., MorozOVA O.V. 2005. Tick-borne pathogen detection in Western Siberia, Russia. Emerg. Infect. Dis. 11: 1708-1715.
Reiter P. 2010: West Nile virus in Europe: understanding the present to gauge the future. Euro Surveill. 15: 19508.

Romanenko V.N., Chekalkina N.B. 2004: [Species composition of ixodid ticks in the territory of Tomsk]. Vestnik Tomsk State Univ. 11: 132-135. (In Russian.)

RyabitseV V.K. 2001: [Birds of the Urals and Western Siberia: Identification Guides]. Ural State University, Ekaterinburg, 608 pp. (In Russian.)

Ryabitsev V.K., Boyko G.V., Moskvitin S.S., Vasilchenko A.A., Gagina T.N., Gashev S.N., Zakharov V.D., Irisova N.L., Korovin V.A., Mitrofanov O.B., Petrov V.Yu.., Soloviev S.A., Strelnikov E.G., Tarasov V.V., Tsybulin S.M., YAKImenko V.V. 2001: [Fauna of birds of Western Siberia regions. Inventory, Monitoring and Protection of Important Ornithological Territories of Russia]. Vol. 3. Russian Bird Conservation Union, Moscow, pp. 140-168. (In Russian.)

Sándor A.D., Kalmár Z., Matei I., Ionică A.M., Mărcuțan, I.-D. 2016: Urban breeding corvids as disseminators of ticks and emerging tick-borne pathogens. Vector Borne Zoonotic Dis. 17: $152-154$.

Sparagano O., George D., Giangaspero A., Špitalská E. 2015: Arthropods and associated arthropod-borne diseases transmitted by migrating birds. The case of ticks and tick-borne pathogens. Vet. Parasitol. 213: 61-66.

Špitalská E., Literák I., Kocianová E., Taragel'ová V. 2011: The importance of Ixodes arboricola in transmission of Rickettsia spp., Anaplasma phagocytophilum, and Borrelia burgdorferi sensu lato in the Czech Republic, Central Europe. Vector Borne Zoonotic Dis. 9: 1235-1241.

Stańczak J., Racewicz M., Michalik J., Cieniuch S., Sikora B., SKoracki M. 2009: Prevalence of infection with Rickettsia helvetica in feeding ticks and their hosts in western Poland. Clin. Microbiol. Infect. 15: 328-329.

State Report on Sanitary and Epidemiological Situation IN TOMSK District in 2017. http://70.rospotrebnadzor.ru. (In Russian.)

Sumner J.W., Nicholson W.L., Massung R.F. 1997: PCR amplification and comparison of nucleotide sequences from the groESL heat shock operon of Ehrlichia species. J. Clin. Microbiol. 35: 2087-2092.

Ternovoi V.A., Protopopova E.V., Chausov E.V., Novikov D.V., Leonova G.N., Netesov S.V., Loktev V.B. 2007: Novel variant of tickborne encephalitis virus, Russia. Emerg. Infect. Dis. 13: $1574-1578$.

Ternovoi V.A., Schelkanov M.Yu., Shestopalov A.M., Aristova V.A., Protopopova E.V., Gromashevskiy V.L., DruZyaka A.V., Slavskiy A.A., Zolotykh S.I., LokteV V.B., Lvov D.K. 2004: [Detection of West Nile virus in birds in the territory of Baraba and Kulunda lowland (West-Siberean migration flyway) in the summer-autumn period of 2002 year]. Vopr. Virol. 3: 52-56. (In Russian.)

Toma L., Mancini F., Di Luca M., Cecere J.G., Bianchi R., Khoury C., Quarchioni E., Manzia F., Rezza G., Ciervo A. 2014: Detection of microbial agents in ticks collected from migratory birds in Central Italy. Vector Borne Zoonotic Dis. 3: 199-205.

Tonetti N., Berggoetz M., Rühle C., Pretorius A. M., Gern L. 2009: Ticks and tick-borne pathogens from wildlife in the Free State Province, South Africa. J. Wildlife Dis. 45: 437-446.

Tsiodras S., Kelesidis T., Kelesidis I., Bauchinger U., FalAGAS M.E. 2008: Human infections associated with wild birds. J. Infect. 56: 83-89.

Ushakova G.V., Filippova N.A., Panova I.V. 1969: [On the types of groups of Ixodes persulcatus (Parasitiformes, Ixodidae). IV. New data on the ecology of Ixodes pavlovskyi Pom. in Eastern Kazakhstan]. Parazitologiya 5: 436-439. (In Russian.)

Wakelin D. 1996: Immunity to Parasites. Cambridge University Press, Cambridge, 204 pp. 
Wheeler S.S., Vineyard M.P., Woods L.W., Reisen W.K. 2012: Dynamics of West Nile virus persistence in house sparrows (Passer domesticus). PLoS Negl. Trop. Dis. 6: e1860.

Wikel S.K., Ramachandra R.N., Bergman D.K., Burkot T.R., Piesman J. 1997: Infestation with pathogen-free nymphs of the tick Ixodes scapularis induces host resistance to transmission of Borrelia burgdorferi by ticks. Infect. Immun. 65: 335-338.
Yabsley M.J., Shock B.C. 2013: Natural history of zoonotic Babesia: role of wildlife reservoirs. Int. J. Parasitol. Parasites Wildl. 2: 18-31.

Yang J., Liu Z., Niu Q., Tian Z., Liu J., Guan G., Liu G., Luo J., WANG X., YIN H. 2015: Tick-borne zoonotic pathogens in birds in Guangxi, Southwest China. Parasit. Vectors 8: 637.

Cite this article as: Korobitsyn I.G., Moskvitina N.S., Tyutenkov O.Y., Gashkov S.I., KononovaY.V., Moskvitin S.S., Romanenko V.N., Mikryukova T.P., Protopopova E.V., Kartashov M.Y., Chausov E.V., Konovalova S.N., Tupota N.L., Sementsova A.O., Ternovoi V.A., Loktev V.B. 2021: Detection of tick-borne pathogens in wild birds and their ticks in Western Siberia and high level of their mismatch. Folia Parasitol. 68: 024. 